\title{
Beds, budgets and burdens: learning disability expenditure v. workload across English health
}

\section{authorities}

\section{Comparative review}

\section{BUNNY FORSYTH and PAUL WINTERBOTTOM}

\author{
Background Following the closure of \\ asylums and widespread changes in the \\ population distribution of people with \\ learning disabilities, there has been little \\ investigation of changing expenditure \\ requirements of health authorities in \\ England.
}

\begin{abstract}
Aims To compare expenditure on learning disability health services across England with the burden of services regionally, as estimated by numbers of people with learning disabilities.
\end{abstract}

\begin{abstract}
Method A national database was set up using data from the National Audit Commission and the Department of Health. The spend/burden ratio was calculated and correlation tests for likely causes of inequality were applied.
\end{abstract}

\section{Results There is widespread discrepancy from the median spend/ burden ratio of $£ 10260$ per person with learning disability. There is a positive correlation between ratios and levels of net exports of people funded by their local authority social services to reside 'out of area'. Comparative underspending occurs in rural areas.}

\section{Conclusions There are inequalities in levels of spending on learning disability services. Comparison of regions suggests resources may not be allocated fairly. Health authorities should ensure that population increases are mirrored by appropriate adjustments in expenditure.}

Declaration of interest $\quad$ B. F. \& P.W. work for Gloucestershire, a rural county.
Local experiences of lack of resources in services for people with learning disabilities, coupled with expanding population size, have caused concern over whether this reflects a nationwide problem. The importance of equity in mental health services (Acheson, 1998) is clear. Recent work has looked at allocation processes for mental health care and learning disability services (Glover, 1999; Bindman et al, 2000). Literature searches reveal no previous work investigating health authority spending on learning disability services or its reflection on population distribution. This seems pertinent, given widespread demographic changes following asylum closures and introduction of community services. While long-stay hospital placements have reduced, residential provision has rapidly expanded.

Specialist residential care provision in some regions has allowed people with learning disabilities to be funded by their local social services to reside 'out of area' if similar local provision is not possible. If there are ongoing mental health needs, these should theoretically be funded by payment from the original health authority to the 'out of area' health authority through a service level agreement. This should compensate for any extra burden on health services in 'receiver' areas. We suspect that this often does not happen.

Allocation formulas do not address the specific needs of the population with learning disabilities. Inherent difficulties in fair allocations and the need for better research are well recognised (Judge \& Mays, 1994). We tackle this complex issue by ascertaining the correlation between health authority spending and the overall burden on learning disability services regionally.

\section{METHOD}

\section{Expenditure on learning disability}

Data collated from the National Audit Commission gave figures for the total expenditure on adult learning disability services reported by each health authority in England for the year 1998-1999. Crude population figures were collated to allow prevalence estimates. Weighted population figures (accounting for differences in age and local market forces) were not used, as their calculation takes no account of differances in the learning disability population. Figures for some geographically divided areas were combined. This enabled accurate comparison with residential data provided by services given only for the larger region (e.g. North and South Essex data were combined to give a figure for Essex). Figures excluded expenditure on forensic and child learning disability services.

\section{Calculation of the total burden}

This calculation aimed to ascertain the total number of adults with learning disabilities residing within each health authority area. The relative levels of specialist service need and socio-economic or demographic variables were not addressed.

Data were obtained from the community care statistics published by the Department of Health (2000), for all adults aged 18 years and over with learning disabilities. This total gave the number of adults with learning disabilities in registered homes; these included residential, dual-registered (although excluding general adult mental health placements), small (three people or fewer), voluntary, private, local authority social-servicefunded and nursing home establishments. Figures were verified by approaching three health authorities directly and comparing these totals with the lists of individual establishments. Hospital and prison populations were excluded. In addition, Department of Health information was used to obtain the numbers of adults with learning disabilities helped to live at home (Department of Health, 1999a). This included those accessing any form of help from social or health services such as welfare benefits, but specifically excluded people in residential care, to prevent double counting. These figures were added to give the total burden: the approximate number of all adults with learning disabilities resident in that region. An estimate of the prevalence of learning disabilities was calculated by expressing the total burden as a percentage of crude population figures. 


\section{Calculation of the spend/burden ratio}

The total expenditure on learning disability services for each health authority was divided by the total burden for the same region to give a spend/burden ratio, a tool devised for the purpose of this research. Expressed as a formula, this is

total expenditure on services $(£ 000)$ total burden $(n)$

giving a spend/burden ratio in $£ 000$ per person with learning disability.

As the data were not normally distributed, we calculated the median value of the ratios to prevent results skew by extremes. The ratios of the individual health authorities were compared with this figure; a ratio significantly less than the median value suggests comparative underspending.

\section{Confounding factors}

Potential confounding factors that might have influenced results were associated with the following factors.

(a) Long-stay hospital data showing bed occupancy by adults with learning disabilities in 1998-1999 (Department of Health, 1999c) were used. These beds are the remaining old asylum placements, so are home for those who occupy them, although funded by health providers. These people would therefore not show up in our burden calculations.

(b) The Office for National Statistics area classification groups health authorities into similar regional types based on a range of demographic and socioeconomic census variables (Bailey et al, 1999). These include, for example, 'coalfields', 'resort and retirement', 'growth areas' and 'ports and industry'.

(c) Data showing the number of residential placements funded by local authority social services (Department of Health, 2000) were expressed as a percentage of all local residential placements. The placements are reassigned to the original social service region, even if the individual is living in another area. If local authorities are funding residential care for more people than there are local placements (i.e. a figure over $100 \%$ ), the people concerned must be residing 'out of area' and there is a net export.

Spearman's rank correlation was used to assess positive or negative correlation between the spend/burden ratio and long-stay data, comparator grouping, or percentage of local-authority-funded placements.

\section{RESULTS}

A database was set up to compare all the collated data (Table 1). Five out of 100 health authorities were excluded owing to lack of residential figures: Morecambe Bay, East Kent, West Kent, West Pennine and North West Anglia. Some geographically close health authorities were amalgamated to account for the combination of social services and Audit Commission data (e.g. North and South Staffordshire; North and South Essex). In total, 84 regions were included in the database. The suggested prevalence of learning disability ranged from 0.1 to $0.49 \%$.

Total health expenditure on learning disability services ranged from $£ 2864000$ (Herefordshire) to $£ 63751000$ (East and West Surrey). The total burden ranged from 273 (Stockport) to 3839 (Lancashire). The spend/burden ratio varied from 4.23 (Lincolnshire) to 27.99 (Stockport), the median being 10.26 ( $£ 000$ per person with

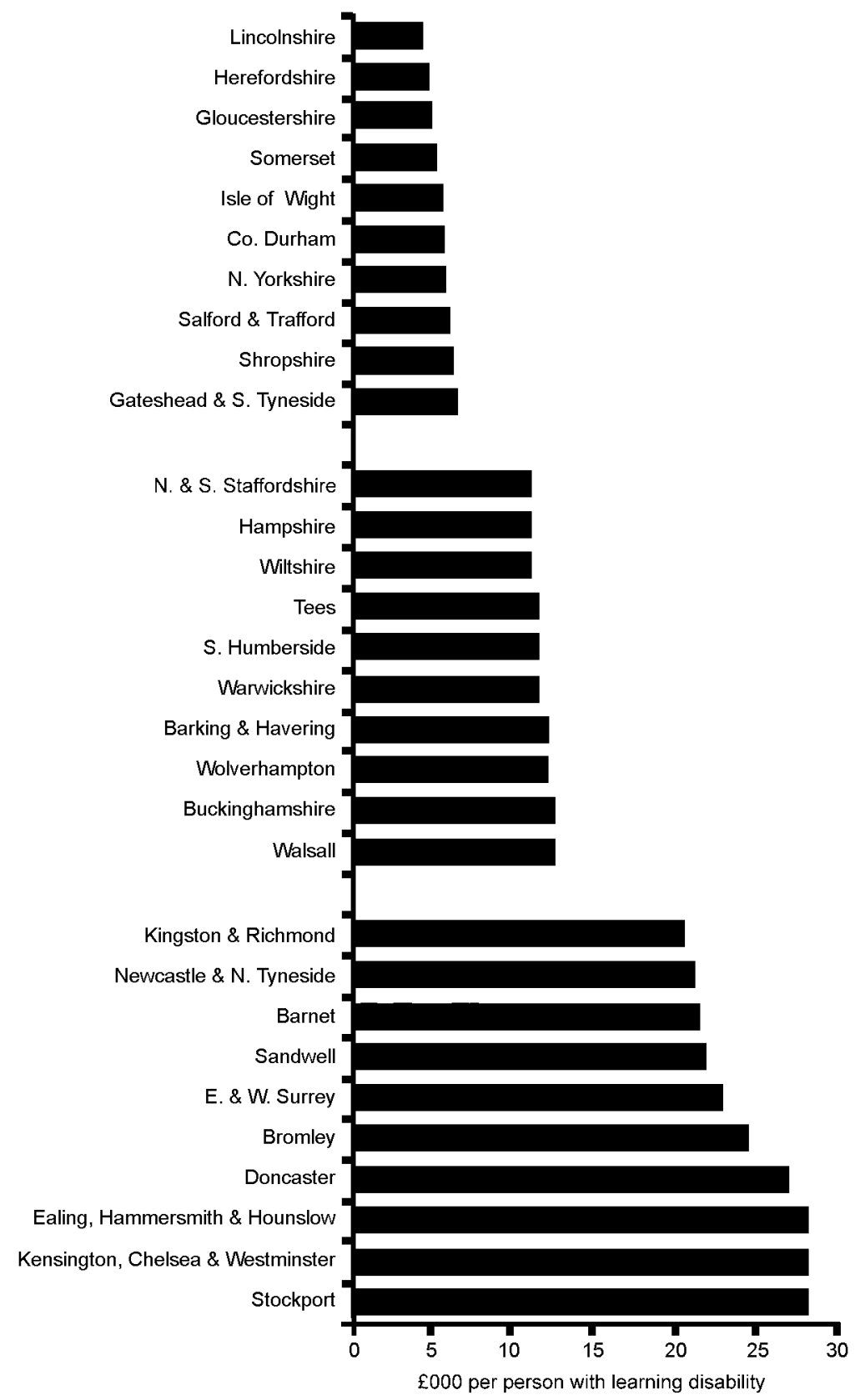

Fig. I Spend/burden ratios of the ten highest, middle and lowest ranking English health authorities, 1998-1999. 
Table I Learning disability services expenditure and residential burden across English health authorities, 1998-1999

\begin{tabular}{|c|c|c|c|c|c|c|c|}
\hline Health authority & $\begin{array}{l}\text { Total expenditure } \\
\text { on learning } \\
\text { disability services } \\
(£ 000)\end{array}$ & $\begin{array}{c}\text { Crude } \\
\text { population } \\
(n)\end{array}$ & $\begin{array}{l}\text { Total } \\
\text { burden' } \\
(n)\end{array}$ & $\begin{array}{l}\text { Prevalence of } \\
\text { learning } \\
\text { disabilities }{ }^{2} \\
\text { (\%) }\end{array}$ & $\begin{array}{l}\text { Average number } \\
\text { of adults in } \\
\text { long-stay } \\
\text { occupied beds } \\
\text { (n) }\end{array}$ & $\begin{array}{l}\text { Percentage of } \\
\text { placements } \\
\text { funded by local } \\
\text { authority social } \\
\text { services }^{3}(\%)\end{array}$ & $\begin{array}{c}\text { Spend/burden } \\
\text { ratio ( } £ 000 \text { per } \\
\text { person with } \\
\text { learning } \\
\text { disability) }\end{array}$ \\
\hline Lincolnshire & 12869 & 623130 & 3038 & 0.49 & 26 & 33 & 4.23 \\
\hline Herefordshire & 2864 & 167920 & 649 & 0.39 & 8 & 20 & 4.41 \\
\hline Gloucestershire & II 355 & 557257 & 2488 & 0.45 & 77 & 32 & 4.56 \\
\hline Somerset & 10367 & 489280 & 2105 & 0.43 & 8 & 45 & 4.92 \\
\hline Isle of Wight & 3209 & 126989 & 601 & 0.47 & 10 & 13 & 5.34 \\
\hline Co. Durham & 9620 & 607770 & 1798 & 0.30 & 55 & 21 & 5.35 \\
\hline N. Yorkshire & 13253 & 742404 & 2428 & 0.35 & 73 & 42 & 5.46 \\
\hline Salford \& Trafford & II 400 & 446222 & 1962 & 0.42 & 0 & 67 & 5.81 \\
\hline Shropshire & 8596 & 430212 & $|44|$ & 0.33 & 7 & 49 & 5.97 \\
\hline Gateshead \& S. Tyneside & 10860 & 353466 & 1754 & 0.50 & 48 & 39 & 6.19 \\
\hline St Helens \& Knowsley & 5126 & 333002 & 823 & 0.25 & 0 & 35 & 6.22 \\
\hline Manchester & 9389 & 429812 & 1490 & 0.36 & 0 & 154 & 6.30 \\
\hline Wirral & 8110 & 327145 & 1256 & 0.38 & 0 & 42 & 6.45 \\
\hline Leicestershire & 21114 & 928716 & 3180 & 0.34 & 94 & 40 & 6.60 \\
\hline E. Norfolk & 15035 & 628094 & 2266 & 0.36 & 192 & 43 & 6.64 \\
\hline North Nottinghamshire & 9905 & 388889 & $147 \mid$ & 0.38 & 6 & 33 & 6.73 \\
\hline Cambridge \& Huntingdon & $1|20|$ & 467980 & 1618 & 0.35 & 2 & 55 & 6.92 \\
\hline Sefton & 7352 & 287743 & 1062 & 0.37 & 0 & 26 & 6.92 \\
\hline S., W., N. \& E. Devon & 25656 & 1068388 & 3661 & 0.34 & 9 & 29 & 7.01 \\
\hline N. Cumbria & 8494 & 319255 & 1165 & 0.36 & 10 & 31 & 7.29 \\
\hline Calderdale \& Kirklees & 9797 & 583774 & 1342 & 0.23 & 0 & 42 & 7.30 \\
\hline Coventry & 5307 & 304334 & 717 & 0.24 & 0 & 54 & 7.40 \\
\hline E. Sussex, Brighton \& Hove & 17461 & 747183 & 2265 & 0.30 & 13 & 34 & 7.70 \\
\hline Barnsley & 3648 & 228103 & 456 & 0.20 & 0 & 211 & 8.00 \\
\hline Rotherham & 5546 & 254424 & 669 & 0.26 & 50 & 49 & 8.30 \\
\hline Redbridge \& Waltham Forest & 14147 & 453316 & 1631 & 0.36 & 10 & 119 & 8.67 \\
\hline Northumberland & 9342 & 309642 & 1072 & 0.35 & 147 & 49 & 8.71 \\
\hline Dorset & 10692 & 691215 & 1224 & 0.17 & 192 & 61 & 8.74 \\
\hline Northamptonshire & 14658 & 615796 & 1660 & 0.27 & 97 & 53 & 8.83 \\
\hline Dudley & 6321 & 311468 & 732 & 0.24 & 46 & 30 & 8.84 \\
\hline Cornwall \& Isles of Scilly & 12075 & 490370 & 1359 & 0.28 & 0 & 32 & 8.89 \\
\hline Enfield \& Haringey & 9647 & 486441 & 1056 & 0.22 & 0 & 102 & 9.14 \\
\hline N. \& S. Derbyshire & 24140 & 937649 & 2608 & 0.28 & 152 & 41 & 9.26 \\
\hline Wakefield & 6927 & 318804 & 737 & 0.23 & 85 & 29 & 9.40 \\
\hline Solihull & 5665 & 205649 & 599 & 0.29 & 0 & 54 & 9.45 \\
\hline Suffolk & 13461 & 671095 & 1383 & 0.21 & 0 & 25 & 9.73 \\
\hline Oxfordshire & 16552 & 616707 & 1679 & 0.27 & 0 & 90 & 9.86 \\
\hline Leeds & $1745 \mid$ & 727389 & 1758 & 0.24 & 107 & 69 & 9.93 \\
\hline Worcestershire & 19391 & 538200 & 1930 & 0.36 & 0 & 44 & 10.05 \\
\hline Bradford & 10639 & 483285 & 1057 & 0.22 & 14 & 60 & 10.07 \\
\hline E., S. \& NW Lancashire & 38792 & $|290| 68$ & 3839 & 0.30 & III & 50 & 10.10 \\
\hline W. Sussex & 17953 & 751845 & 1773 & 0.24 & 0 & 71 & 10.13 \\
\hline N. \& S. Staffs & 24134 & I 061280 & 2322 & 0.22 & 69 & 47 & 10.39 \\
\hline North, Mid, SE \& SW Hampshire & 37792 & I 643958 & 3570 & 0.22 & 132 & 57 & 10.58 \\
\hline Wiltshire & 16386 & 605511 & 1519 & 0.25 & 22 & 58 & 10.79 \\
\hline Tees & 16670 & 556344 & 1504 & 0.27 & 12 & 63 & 11.08 \\
\hline
\end{tabular}


Table I (continued)

\begin{tabular}{|c|c|c|c|c|c|c|c|}
\hline Health authority & $\begin{array}{l}\text { Total expenditure } \\
\text { on learning } \\
\text { disability services } \\
(£ 000)\end{array}$ & $\begin{array}{c}\text { Crude } \\
\text { population } \\
(n)\end{array}$ & $\begin{array}{c}\text { Total } \\
\text { burden' } \\
\text { (n) }\end{array}$ & $\begin{array}{l}\text { Prevalence of } \\
\text { learning } \\
\text { disabilities } \\
\text { (\%) }\end{array}$ & $\begin{array}{l}\text { Average number } \\
\text { of adults in } \\
\text { long-stay } \\
\text { occupied beds } \\
\text { (n) }\end{array}$ & $\begin{array}{l}\text { Percentage of } \\
\text { placements } \\
\text { funded by local } \\
\text { authority social } \\
\text { services }^{3}(\%)\end{array}$ & $\begin{array}{l}\text { Spend/burden } \\
\text { ( } £ 000 \text { per } \\
\text { person with } \\
\text { learning } \\
\text { disability) }\end{array}$ \\
\hline S. Humberside & 5596 & 308584 & 498 & 0.16 & 18 & 69 & 11.24 \\
\hline Warwickshire & 13423 & 506713 & 1189 & 0.23 & 146 & 35 & 11.29 \\
\hline Barking \& Havering & 7238 & 383888 & 608 & 0.16 & 0 & 107 & 11.90 \\
\hline Wolverhampton & 6679 & 241623 & 560 & 0.23 & 13 & 47 & 11.93 \\
\hline Buckinghamshire & 13676 & 681873 & 1135 & 0.17 & 100 & 67 & 12.05 \\
\hline Walsall & 7347 & 261170 & 598 & 0.23 & 68 & 62 & 12.29 \\
\hline Liverpool & 13835 & $46|48|$ & 1106 & 0.24 & 0 & 45 & $|2.5|$ \\
\hline Hillingdon & 6456 & 251165 & 516 & 0.21 & 0 & 119 & 12.51 \\
\hline Lambeth, Southwark \& Lewisham & 20314 & 745240 & 1615 & 0.22 & 0 & 115 & 12.58 \\
\hline Berkshire & 28713 & 800180 & 2248 & 0.28 & 9 & 48 & 12.78 \\
\hline Sheffield & 13678 & $53|14|$ & 1064 & 0.20 & 6 & 43 & 12.85 \\
\hline Bexley \& Greenwich & II 644 & 432933 & 901 & 0.21 & 0 & 114 & 12.92 \\
\hline Birmingham & 29009 & 1013431 & 2221 & 0.22 & 144 & 50 & 13.06 \\
\hline Camden \& Islington & 6998 & 367569 & 530 & 0.14 & 0 & 175 & 13.20 \\
\hline Wigan \& Bolton & 12028 & 577985 & 816 & 0.14 & 0 & 109 & 14.74 \\
\hline N. \& S. Essex & 52423 & 1605622 & 3527 & 0.22 & 371 & 15 & 14.86 \\
\hline Brent \& Harrow & 14367 & 464447 & 922 & 0.20 & 23 & 76 & 15.58 \\
\hline Bedfordshire & 16283 & 556628 & 1028 & 0.18 & 0 & 60 & 15.84 \\
\hline Bury \& Rochdale & II 545 & 391007 & 725 & 0.19 & 0 & 97 & 15.92 \\
\hline E. London \& The City & 14888 & 612425 & 932 & 0.15 & 5 & 123 & 15.97 \\
\hline Sunderland & 11305 & 292307 & 678 & 0.23 & 12 & 78 & 16.67 \\
\hline East Riding & 14137 & 574533 & 814 & 0.14 & 0 & 37 & 17.37 \\
\hline Nottingham & II 375 & 642698 & 629 & 0.10 & 76 & 37 & 18.08 \\
\hline E, N. \& W. Herts & 38944 & 1033616 & 2119 & 0.21 & 6 & 67 & 18.38 \\
\hline Croydon & 13760 & 338217 & 738 & 0.22 & 0 & 49 & 18.64 \\
\hline N. \& S. Cheshire & 33090 & 984280 & 1735 & 0.18 & 6 & 42 & 19.07 \\
\hline Merton, Sutton \& Wandsworth & 26807 & 626992 & 1334 & 0.21 & 217 & 108 & 20.10 \\
\hline Avon & 44581 & 999295 & 2215 & 0.22 & 260 & 33 & 20.13 \\
\hline Kingston \& Richmond & II 574 & 334032 & 574 & 0.17 & 0 & 69 & 20.16 \\
\hline Newcastle \& N. Tyneside & 16313 & 470071 & 780 & 0.17 & 0 & 30 & 20.91 \\
\hline Barnet & II 291 & 331548 & 533 & 0.16 & 0 & 144 & 21.18 \\
\hline Sandwell & II 485 & 290521 & 533 & 0.18 & 23 & 52 & 21.55 \\
\hline E. \& W. Surrey & 63751 & I $06054 \mid$ & 2824 & 0.27 & 493 & 48 & 22.57 \\
\hline Bromley & 8193 & 297118 & 339 & 0.11 & 0 & 228 & 24.17 \\
\hline Doncaster & 10965 & 290468 & 411 & 0.14 & 49 & 29 & 26.70 \\
\hline Ealing, Hammersmith \& Hounslow & 24957 & 671169 & 896 & 0.13 & 0 & 114 & 27.85 \\
\hline $\begin{array}{l}\text { Kensington, Chelsea \& } \\
\text { Westminster }\end{array}$ & 9244 & 390772 & 331 & 0.08 & 0 & 252 & 27.92 \\
\hline Stockport & 7643 & 292808 & 273 & 0.10 & 0 & 260 & 27.99 \\
\hline
\end{tabular}

I. Number of placements plus number of people with learning disabilities helped to live at home.

2. Total burden divided by crude population figure, expressed as percentage.

3. Values exceeding $100 \%$ indicate net export.

learning disability). Figure 1 contrasts the ten regions with the highest, middle and lowest rankings.

The health authorities were grouped by comparator data, e.g. all regions classified as growth areas. Spend/burden ratios showed no correlation, having randomly high or low values within these groupings (Fig. 2). Health authority spend/burden ratios were then compared with the percentage of local-authority-funded placements. This relationship had a statistically significant positive correlation (Spearman's rank correlation, two-tailed, 0.413, $P<0.001$ ). Net exporters (with values greater than $100 \%$ ) were seen in increasing numbers as the spend/burden ratio increased. There were none in the ten 


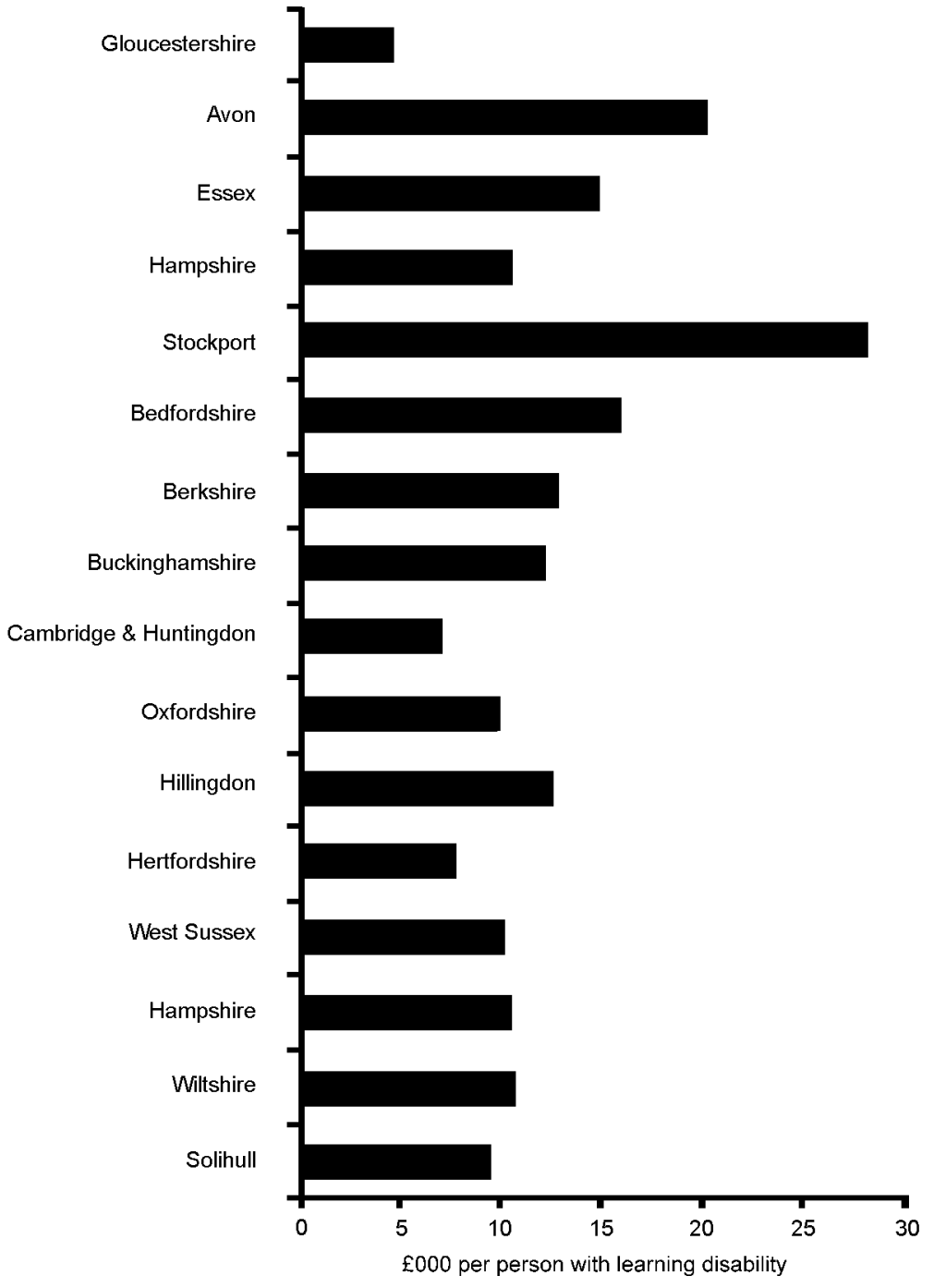

Fig. 2 Spend/burden ratios of health authorities grouped by Office for National Statistics classification into comparator 'growth areas', 1998-1999.

lowest-ranked authorities, one in the middle-placed and five in the highestplaced regions (Fig. 3). Numbers of long-stay hospital placements (which would not register in other residential figures) showed no correlation with spend/burden ratios (Spearman's rank correlation, two-tailed, $-0.113, P=0.31$ ).

\section{Verification of figures}

Verification of the accuracy of Department of Health registrations data was attempted by approaching three health authorities directly, namely South Gloucestershire, Bristol and Hampshire, who provided detailed lists of all residential establishments in their region, together with the population figures for each home. These figures were added together, then divided by the Department of Health figure to express a positive or negative percentage deviation. There was a deviation in numbers of $2.5 \%(485 / 473),-5.1 \%$ $(788 / 830)$ and $-3.6 \%(1036 / 1075)$ respectively. This suggests a maximum margin of error of $5 \%$.

\section{DISCUSSION}

\section{Limitations of the study}

\section{Data provision}

The figure for expenditure is that given by individual health authorities to the Audit Commission. It does not necessarily translate into direct provision on the ground because of different interpretations of which facilities, staff, resources and administrative costs accurately come under the 'learning disability' umbrella. In interpreting the results, therefore, this may be an issue for clinicians to clarify directly if spend figures seem out of step with actual resources.

The data used to calculate the total burden were derived from social services, and there may well be regional differences in the accuracy of the figures obtained. However, there is no other available source of such data at present. We must assume the accuracy of the data collected but there is no independent means of validation.

\section{Excluded categories}

A section of the population with learning disability is, by definition, excluded from this study; these are adults with learning disabilities who live at home alone or with their families and do not receive any form of help from health or social services, including welfare benefits. To include this group was beyond the means of this study. A larger group of people with mild learning disabilities ( $I Q=55-69)$ living independent lives and not identifying themselves as having disabilities are also excluded.

The IQ test with mean 100 (s.d. 15) is normally distributed in populations, giving a predicted $2.27 \%$ of the population falling below $\mathrm{IQ}=70$ (used to define learning disability). However, there is also a small effect below $\mathrm{IQ}=50$ from specific pathological conditions. Some data confirm these figures (Rutter et al, 1976; Szymanski \& Kaplan, 1997). However, the percentages identified in other prevalence studies of $0.3 \%$ to $0.65 \%$ (Fryers, 1993; Van Schrojenstein Lantman-De Valk, 1997) correlate with the figures obtained here, illustrating the difficulty of including all who qualify. Few reliable sources for prevalence estimation exist because of varying selection criteria and case-finding methods, as well as variations in age and in temporal and social factors (Fryers, 1997).

\section{Financial complexities}

Unusual forms of purchasing arrangements can cloud accurate spend figures. There are funds known as 'Section 28 transfers', which allow the movement of funds from health authorities to local authorities. These are applied to people who were resident in long-stay hospitals before April 1971. This money follows the individual until movement out of National Health Service (NHS) care or death, and counts against health authority expenditure. Owing to the complexity of care provisions, with different health authorities making different arrangements 


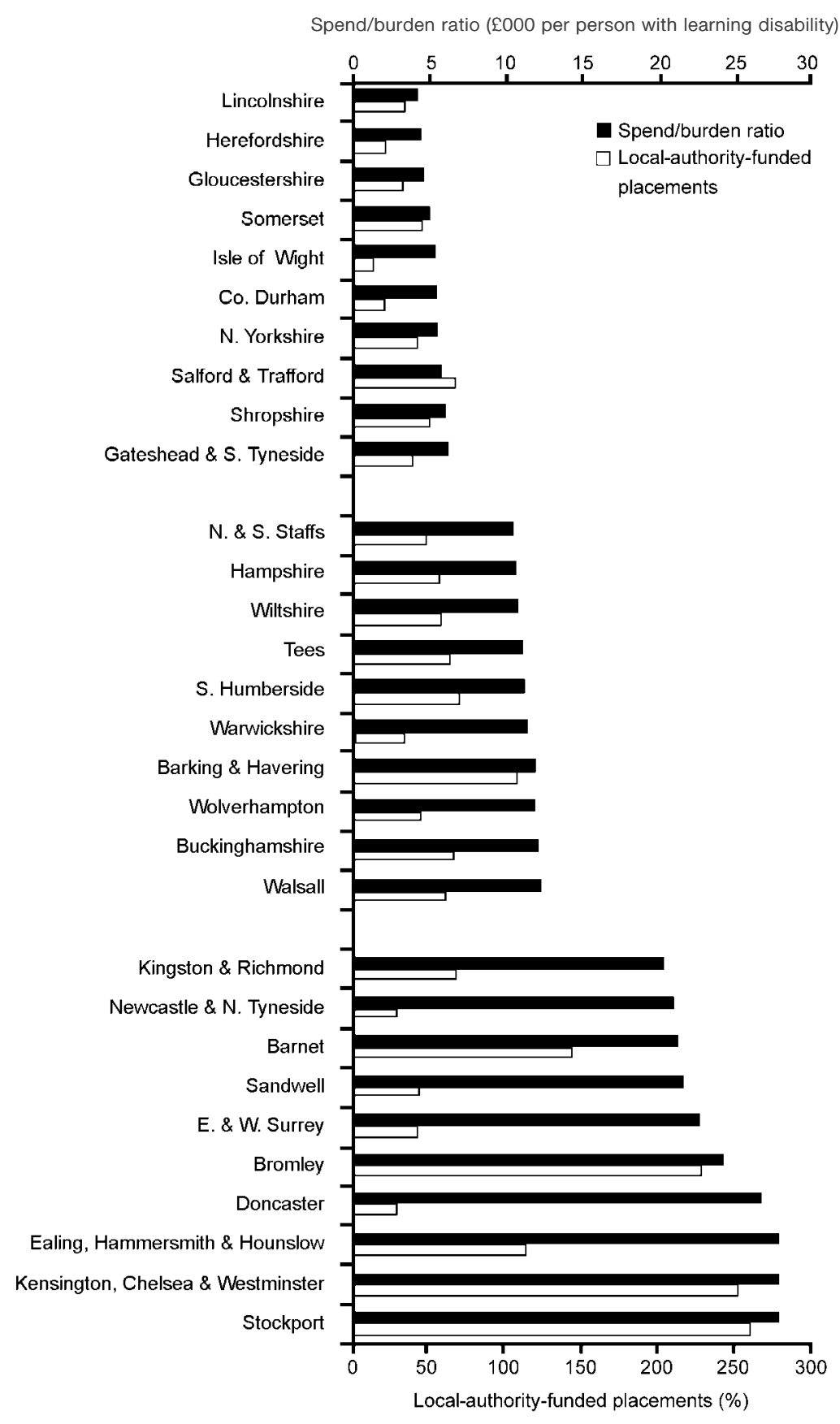

Fig. 3 The spend/burden ratios of the highest-, middle- and lowest-ranking health authorities have a positive correlation with the proportion of residential placements that are funded by the local authority (values $>100 \%$ indicate a net export). Spearman's rank correlation $0.413, P<0.001$.

for the continuing care of former asylum residents, exact expenditure has become difficult to untangle. Other funds, not tied to individuals, may also count against spend; these are now under investigation by the Department of Health.

Further complication may arise from health authorities using 'health' funds to provide what is effectively social care, funding which should be provided by social services. Old long-stay beds are an example for which we have accounted, but other residential placements of people with high-level needs may have a percentage of their specialist residential care paid for by the health budget. The definitions for these provisions and standard percentage contributions for such cases may vary across the country, and we have no means of tracking them individually.

\section{Provision for autism and children's services}

A further complicating factor is that of provision for children with learning disabilities. Although spend figures are supposed to represent adult expenditure only, there are very different practices across England in how child and adolescent mental health services liaise with learning disability services. In addition, some regions provide services for autisticspectrum disorder under the learning disability services umbrella, whereas others do not. This could well be mirrored by different financial arrangements allowing for transitional services and dual working.

\section{Differences in spend/burden ratios}

There appear to be large discrepancies nationally in the spend/burden ratios, with some health authorities spending far less on services in relation to the number of people with learning disabilities than do others. This study makes no attempt to define adequate levels of spending, merely to make comparisons with a national median. Whether there is national underresourcing, adequate resourcing or even overresourcing, the emerging picture strongly suggests a widespread disparity between health authorities. It is important to remember that high spending does not necessarily equate with effective use of resources, and that lower relative expenditure may represent more efficient and effective services. Although the quality and costs of residential provision for people with learning disabilities have been investigated (Hatton et al, 1995; Department of Health, $1999 b)$, comparison of spending levels with respect to population numbers has not been reviewed.

\section{Regional differences}

Clarification of data enabling analysis of confounders such as comparator grouping does not seem to explain the spend/burden ratio discrepancies. However, in looking for regional patterns the results show more rural areas with lower expenditure relative to higher burden.

\section{'Exporter' v. 'receiver'areas}

There is significant correlation between spend/burden ratios and the proportions of placements funded by local authority 
social services. Given the rarity of privately funded placements, results suggest that lower-ratio health authorities ('receiver areas') have more imported placements from other regions. Higher-ratio health authorities are significantly more likely to be net exporters. It is notable that all clear exporter health authorities are smaller, urban regions. It may be that it is the geographical size of the region rather than the urban-rural distinction that increases the likelihood of export, with smaller authorities having fewer internal residential resources. It may be cheaper to build residential facilities in rural areas than in cities, and this too could account for greater use of exports to rural regions. 'Out of area' placements are often used where higher levels of specialist services are needed (implying greater health needs). Unless service level agreements are arranged with the receiving health authority, the receiver area funds any future mental health needs. In effect, this can mean that the health burden of such placements is particularly high, this being the experience locally in Gloucestershire. There is an implication that accurate enforcement of service level agreements for all exported people with specialist mental health needs might redress the imbalance of present expenditure patterns. If this is unworkable, overhaul of present allocation methods may be necessary.

Although recent research has looked at the extent of 'out of area' admissions to psychiatric beds in general psychiatry (Glover \& Bindman, 2001), there is no similar research in the learning disability sector, either for hospital or residential 'out of area' placements.

\section{Long-stay hospital data}

The lack of correlation between numbers of long-stay (asylum) placements and spend/ burden ratios is surprising, given that these figures would be an obvious source of discrepancies.

\section{Clinical implications \\ Effect of asylum closure}

The fact that expenditure on learning disability services is not distributed equitably between health authorities mirrors the findings of research into general mental health service expenditure (Bindman et al, 2000). The noted high level of expenditure on general mental health services in London

\section{CLINICAL IMPLICATIONS}

- There are significant financial inequalities in learning disability services across England, which are likely to affect the quality and quantity of clinical care.

- Receiver areas with more imported placements have lower relative expenditure, so potentially worse health outcomes.

- Lower spend/burden ratios indicate that clinical provision in rural 'shire' areas is likely to be limited compared with urban areas.

\section{LIMITATIONS}

- The study excludes a large group of people with mild learning disabilities.

- The complexity of different financial arrangements and degrees of provision for children or autism services may cloud expenditure figures.

- Alternative data sources to verify the accuracy of health and social services statistics are unavailable.

BUNNY FORSYTH, MRCPsych, PAUL WINTERBOTTOM, MRCPsych, Learning Disability Services, Gloucestershire Partnership NHS Trust, UK

Correspondence: Dr Bunny Forsyth, Heathfield, 30 Denmark Road, Gloucester GLI 3HZ, UK. E-mail: bunny.forsyth@blueyonder.co.uk

(First received 2I November 200I, final revision 3 April 2002, accepted 5 April 2002)

(Chisholm et al, 1997) has been attributed to need greater than that accounted for by the York index (Ramsay et al, 1997). Whether this translates into spending on learning disabilities services is unknown. Crucially, the movements of this vulnerable population over the past decade as asylums have closed have not been accounted for in a coherent national approach with regard to relative levels of expenditure. This has created ethical dilemmas (Greaves, 1997).

This study suggests that the export of people out of their home county has not been paralleled by an increase in spending by the receiving counties facing the consequent higher burden. The closure of asylum provision may therefore have occurred at the expense of such receiver areas without adequate follow-through of finances to fund the needed community care.

\section{Political initiatives}

The impact of political initiatives on spending is not documented in learning disability research. The formation of 'health action zones' in areas such as Stockport and Sandwell may have affected their expenditure. Similarly, some areas have pioneered effective joint working between health and social services, as has been done in Hillingdon, and this may have had a beneficial effect on improving the efficiency and profile of the service area.

The White Paper Valuing People: A New Strategy for Learning Disability for the 21st Century (Department of Health, 2001) sets out proposals for improving the lives of all people with learning disabilities. A new learning disability development fund of $£ 22$ million revenue and $£ 20$ million capital is being introduced in 2002 , to ensure implementation. The observed discrepancies suggest that individual health authorities should address potential inequalities, particularly in the light of future budgetary increases, to ensure that people with learning disabilities are optimally and equitably served.

\section{ACKNOWLEDGEMENTS}

We are grateful to Bill Alexander of the National Audit Commission for help in data provision, to Oliver Russell of the Department of Health for data provision and comments, to Chris Foy for statistical 
advice and to Mark Scheepers and Mhairi Duff for critical appraisal.

\section{REFERENCES}

Acheson, D. (1998) Report of the Independent Inquiry into Inequalities in Health. London: Stationery Office.

Bailey, S., Charlton, S., Dollamore, G., et al (1999) The ONS Classification of Local and Health Authorities of Great Britain: Revised for Authorities in 1999. London: Office for National Statistics.

Bindman, J., Glover, G., Goldberg, D., et al (2000) Expenditure on mental health care by English health authorities: a potential source of inequity. British Journal of Psychiatry, 177, 267-274.

Chisholm, D., Lowin, A. \& Knapp, M. (1997) Mental health Services in London: costs. London's Mental Health (eds S. Johnson, R. Ramsay, G. Thornicroft, et al), pp. 305-330. London: King's Fund.

Department of Health (1999a) Audit Commission performance indicators on social services. In Key Indicators Graphical System. KSI Data Item 2. I2A London: Department of Health.
_ (1999b) Quality and Costs of Residential Provision for People with Learning Disabilities. HSC 199/162: LAC (99) 28. London: Department of Health.

- (1999c) Bed Availability and Occupancy 1998-99. KHO3. London: Department of Health

- (2000) Community care statistics 1999. In Statistical Bulletin (ed. T. Kilby). London: Department of Health.

_ (200I) Valuing People: A New Strategy for Learning Disability for the 2lst Century. London: Department of Health.

Fryers, T. (1993) Epidemiological thinking in mental retardation: issues in taxonomy and population frequency. International Review of Research in Mental Retardation, 19, 97-133.

- (1997) Impairment, disability and handicap: categories and classifications. In Seminars in the Psychiatry of Learning Disabilities (ed. O. Russell), pp. 16-30. London: Gaskell.

Glover, G. (1999) How much English health authorities are allocated for mental health care. British Journal of Psychiatry, 175, 402-406.

_\& Bindman, J. (200I) Out of area

hospitalisations - the view from current routine statistics. Psychiatric Bulletin, 25, 376-378.
Greaves, D. (1997) Changing priorities in residential, medical, and social services. Journal of Medical Ethics, 23 $77-81$.

Hatton, C., Emerson, E., Robertson, J., et al (1995) The quality and costs of residential services for adults with multiple disabilities: a comparative evaluation. Research in Developmental Disabilities, 16, 439-60.

Judge, K. \& Mays, N. (1994) Allocating resources for health and social care in England. BMJ, 308, 1363-1366.

Ramsay, R., Thornicroft, G., Johnson, S., et al (1997) Levels of in-patient and residential provision throughout London. London's Mental Health (eds S. Johnson,

R. Ramsay, G. Thornicroft, et al), pp. 193-219. London: King's Fund.

Rutter, M., Tizard, J., Yule, W., et al (1976) Isle of Wight studies, 1964-1974. Psychological Medicine, 6, 313-332.

Szymanski, L. S. \& Kaplan, L. C. (1997) Menta retardation. In Textbook of Child and Adolescent Psychiatry (2nd edn) (ed. J.Weiner), pp. 83-218. Washington, DC: American Psychiatric Press.

Van Schrojenstein Lantman-De Valk, H. M. (1997) People with intellectual disability in general practice: case definition and case finding. Journal of Intellectual Disability Research, 4I, 373-379. 